\title{
Effect of different production types on the yield and B-carotene content of sweet potato /cultivar Ásotthalmi- 12/
}

\author{
Viktor Balázs ${ }^{1}$ - Lajos Helyes ${ }^{1}$ - Zoltán Pék ${ }^{1}$ - András Neményi ${ }^{1}$ - Sándor Takács ${ }^{1}$ - Márton Égei ${ }^{1}$ - \\ Hussein G. Daood ${ }^{2}$ \\ ${ }^{1}$ Szent István University, Department of Horticulture, Gödöllö, Hungary \\ ${ }^{2}$ Szent István University, Regional Knowledge Center, Gödöllő, Hungary \\ balazsvnovenyorvos@gmail.com
}

\begin{abstract}
SUMMARY
Production of sweet potato is extending in Hungary, despite the fact that there is no field-specific production technology. Therefore, many growers cannot utilize potential yields and quality. The goal of this study was to determine the optimal production method of the Asotthalmi 12, a Hungarian sweet potato cultivar which can adapt to the Hungarian climate. The effect of single and twin rows production on the yield of this cultivar was examined. The planting was carried out on June $24^{\text {th }}$, the harvesting on October $20^{\text {th }}$ and the growing-season was 120 days long. Uniform nutrient supply was applied to the whole field experiment. During basic fertilization, $206 \mathrm{~kg} \mathrm{Knd} 20 \mathrm{~kg} \mathrm{~N}, 36 \mathrm{~kg} P$ ha ${ }^{-1}$ were used on the soil. While forming the ridges, we used an additional $25 \mathrm{~kg} \mathrm{~N}, 45 \mathrm{~kg} \mathrm{P}$ and $62.5 \mathrm{~kg} \mathrm{~K} \mathrm{ha-1}$. We adopted drip tape irrigation on the experimental field. After the planting, from the 8 th week of the vegetation, another $21 \mathrm{~kg} \mathrm{ha}^{-1} \mathrm{K,} 10 \mathrm{~kg} \mathrm{ha}^{-1} \mathrm{MgSO}_{4}$, and $\left.2 \mathrm{~kg} \mathrm{ha}^{-1} \mathrm{Ca}_{(\mathrm{NO}}\right)_{2} \mathrm{was}$ added in one dosage weekly, until the $13^{\text {th }}$ week of vegetation. At the evaluation of the experiment, we examined the yield regarding the whole experimental plot. SPAD and fluorescence measurements were carried out on 08.16. 2019, 08.28.2019, and on 09.13.2019, during the watering break. To demonstrate the difference between the dates, we applied ANOVA and Tukey post-hoc tests. For the measurement of phytonutrients HPLC, a liquid chromatograph was used, where the carotenoid content of the Asotthalmi 12 cultivar was determined in connection with the different production methods. Test results showed that twin rows production leads to a nearly $30 \%$ greater yield, than single row production. We determined, that the growth of yield correlates negatively to the $\beta$-carotene content of the Ásotthalmi 12 cultivar sweet potato.
\end{abstract}

Keywords: sweet potato; production; yield; $\beta$-carotene

\section{INTRODUCTION}

Sweet potato is an extremely important food commodity in several countries all over the world. Production was 112 million tons in 2017, and the area was more than 92 million hectare in the world (http1). The consumer trend of the world is going through a significant change. The focus of the consumer is moving towards the positive physiological effects of food, health preservation, and the consumption of functional foods with beneficial nutrients, which have a positive effect on the human health. Currently, the positive physiological effects of phytonutrients are at the centre of international research, which we can gain from fresh and processed vegetables. In Hungary, we are beginning to feel the growing popularity of new trends created by health-conscious consumers, which also affects vegetable consumption. For this reason, sweet potato is one of the most promising vegetables in Hungary, which is a highly demanded product as it has many positive physiological qualities, and it can be easily fitted into the Hungarian gastro world. In Hungary, the naturalization process of sweet potato was started in 1986, by Lajos Horváth, in Tápiószele (Horváth, 1991a; Horváth, 1991b; Horváth, 1991c). Aside from his different production experiments, one of his greatest achievements is the bright orangefleshed, Tápió 96 cultivar, which received state certification in 2003. Others also started the production experiments and naturalization of sweet potato in Hungary in the early 1990s, for example in Ásotthalom.

In Hungary, Ásotthalom, Berzence, Nyírség, and nowadays Heves, are the main locations of sweet potato production, however, the circle of producers is continuously expanding. For Hungarian producers, the only available production recommendations are the ones issued by NÖDIK and Bivalyos Tanya Kft. (Monostori et al., 2015).

Unfortunately, despite the decades old experiences, Hungarian production recommendations lack field specific experiments, and those production methods experiences, which allow for the realization of high and quality harvest level. There are no field-specific recommendations for the production technology in Hungary which would provide high quality and quantity yield. With our research, we would like to contribute to the improvement of Hungarian sweet potato production technology. Furthermore, we aim to provide a reliable source of food, with high nutritional content, for those who battle diabetes and cancer.

\section{MATERIALS AND METHODS}

\section{Comparison of different production techniques}

During our experiment, we studied the Ásotthalmi 12 Hungarian cultivar and compared its quantity and quality in different production environments. From the aspect of production technology, we studied the ridge, simple row, and twins rows production, and their way of affecting harvest quantity. During planting, we used $30 \mathrm{~cm}$ planting distance and $90 \mathrm{~cm}$ row spacing. In the four repeating experiments, one plot covered a $12.5 \mathrm{~m}^{2}$ area. In the case of twins rows $(30 \mathrm{~cm}$ between plants in zigzag pattern), 35.000 plantlets were planted per hectare, while in the case of single rows, 17.500 plantlets were planted per hectare. There was $90 \mathrm{~cm}$ 
between the twin rows $(30 \mathrm{~cm}$ between the two rows in the twin row system) and $30 \mathrm{~cm}$ between plants.

In India, the usage of smaller spacing is advised, to maximize the harvest quantity of sweet potato. Row spacing should range from 30 to $60 \mathrm{~cm}$, while the ideal distance between the plants should range from 15 to 20 $\mathrm{cm}$, in order to maximize harvest quantity (Patil et al., 1992). The applied cultivars play an important role in the formation of harvest quantity. Many research studies aim to create a cultivar that adapts to local conditions and leads to high quantity (Nedunchezhiyan et al., 2012).

The planting was carried out on June $24^{\text {th }}$. the harvesting on October $20^{\text {th }}$. and the growing-season was 120 days long. Uniform nutrient supply was applied to the whole field experiment. During basic fertilization, $206 \mathrm{~kg} \mathrm{ha}^{-1} \mathrm{~K}$ and $20 \mathrm{~kg} \mathrm{~N}, 36 \mathrm{~kg}$ P per hectar were used on the soil. While forming the ridges, we used an additional $25 \mathrm{~kg} \mathrm{~N}, 45 \mathrm{~kg} \mathrm{P}$ and $62.5 \mathrm{~kg} \mathrm{~K}$ per hectar. We adopted drip tape irrigation on the experimental land, similarly to the work land. After the planting, from the $8^{\text {th }}$ week of the vegetation, another $21 \mathrm{~kg} \mathrm{~K}, 10 \mathrm{~kg} \mathrm{MgSO}_{4}$, and $2 \mathrm{~kg} \mathrm{Ca}\left(\mathrm{NO}_{3}\right)_{2}$ per hectar was added in one dosage weekly, until the $13^{\text {th }}$ week of vegetation.

We formed ridges covered with agro foil. The foil cover method helps with the eradication of weeds, without herbicide. Moreover, it provides a favourable microclimatic environment for sweet potato. Throughout the experiment, we carried out plant physiology measurements; chlorophyll fluorescence, and chlorophyll content measurement, to accurately determine plant conditions.

At the evaluation of the experiment, we examined the yield regarding the whole experimental plot. SPAD (Soil Plant Analysis Development) with a SPAD 502 (Minolta, UK) and fluorescence with a PAM-2500 fluorimeter (Walz-Mess und Regeltechnik, Germany) measurements were carried out on 08.16. 2019, 08.28. 2019, and on 09.13.2019, during the watering break. The SPAD index numbers show a close connection between yield, nitrogen supply, and chlorophyll content (http2). The gauge determines the values, by the absorption of $650 \mathrm{~nm}$ wavelength beams. The device uses infra-red as a reference value in the $940 \mathrm{~nm}$ range. To demonstrate the difference between the dates, we applied ANOVA and Tukey post-hoc tests.

The experiment was carried out on sandy soil and physical texture content as clay $10 \%$, silt $10 \%$, sand $80 \%$ and humus content below $1 \%$.

Meterology data shows the minimum, maximum and average temperature ${ }^{\circ} \mathrm{C}$, besides the monthly precipitation amount in 2019 (OMSZ).

Figure 1. Meterology data (OMSZ)

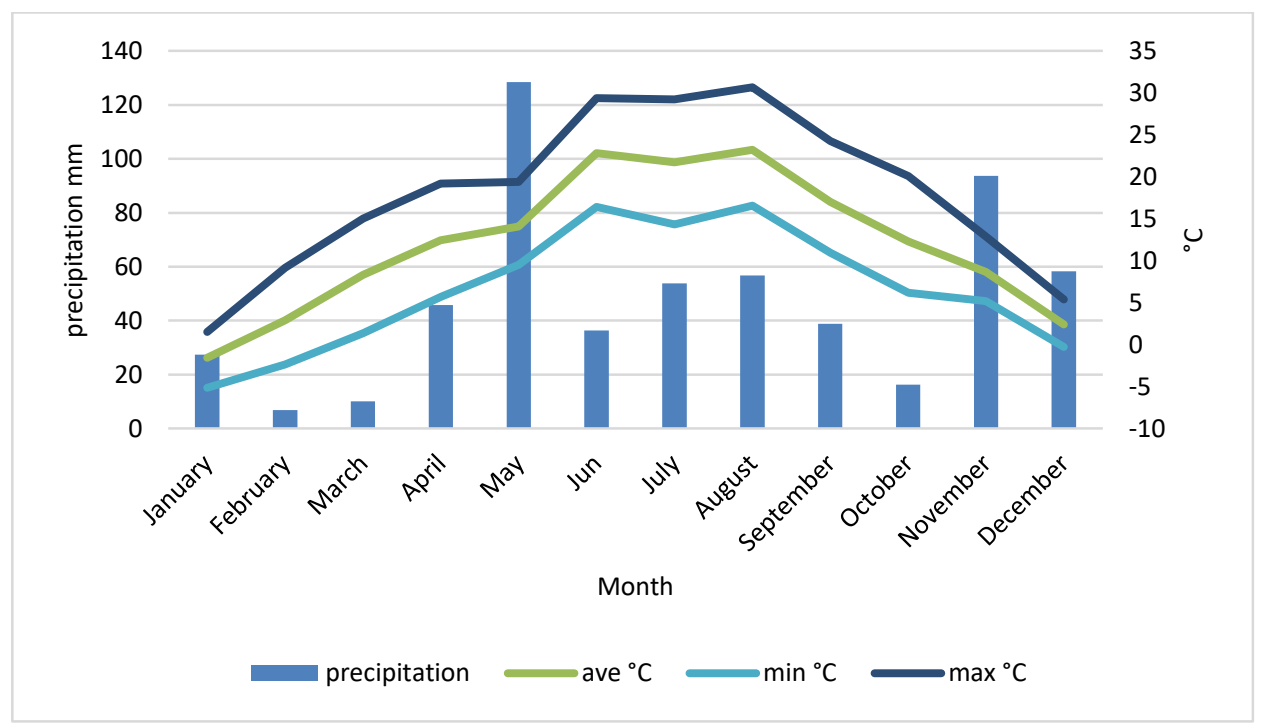

Normality was monitored by Shapiro-Wilk test. The Homogeneity of variance was checked by Bartlett test. For the determination of the effects of single and twin rows production on the yield, we used Student T test.

\section{Examination of nutritional parameters}

For the measurement of phytonutrients HPLC, a liquid chromatograph was used, where the carotenoid content of the jonquil meat Ásotthalmi 12 cultivar was determined in connection with the different production methods.
During the experiment, $5 \mathrm{~g}$ sweet potato was mushed, then, after the quartz sand rubbing process, 20 $\mathrm{ml}$ organic methanol solvent was used. Following the affusion, $10 \mathrm{ml}$ methanol and $55 \mathrm{ml} \mathrm{1,2} \mathrm{dichloro-ethane}$ was applied. This procedure was repeated three times to obtain proper solving. A filter paper was used for the filtration of the solution, and the liquid phase was evaporated. After the dissolution, the B-carotin content of the sweet potato was examined with the HPLC. 


\section{RESULTS AND DISCUSSION}

The effect of twin and single rows on soil moisture

The second graph demonstrates soil moisture rates in the case of single and twins rows, in ridge production. On. August $16^{\text {th }}, 2019$ watering was paused, to help tuber formation. Figure 1 displays that in the case of twins rows, soil moisture was lower, than in the case of single rows. Regarding the twin rows, the greater plant density per unit area leads to the utilization of water surplus. Soil moisture $(\mathrm{m} / \mathrm{m} \%)$ was significantly higher at the first measurement, than at the other two dates (Figure 2).

Figure 2. Soil moisture (Soil Moisture PT1 (Kapacitív Kkt., Hungary) rates in three different times of measurements, the different letters mark the significant difference between dates of measurements $(\mathrm{p}<0.001, \mathrm{n}=4)$

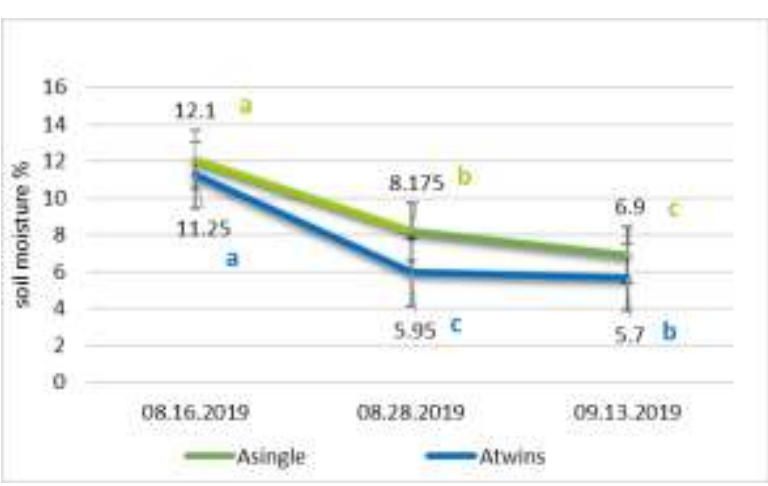

The evaluation of different production methods, with fluorescence measurement

With the chlorophyll fluorescence, the change in the photosynthetic activity of the Ásotthalmi 12 cultivar sweet potato was measured. This method is based on the measurement of the induction of chlorophyll-a fluorescence. There is a close connection between the fluorescence mark and the state of the photosynthetic electron transport chain determined by the Fv/Fm ratio. The measurements show that the rates increase linearly, which is the result of the long warm period at the end of summer, and the beginning of autumn (Figure 1). There is no significant difference in photosynthetic activity between the application of twin- and single row production. Being a tropical, subtropical plant, sweet potato adapts to water stress, caused in the last third of vegetation, and adapts to the droughty, warm season, which can also be seen in the growth of vegetation activity (Figure 3).

\section{SPAD value measurement throughout the process of single and twin rows production}

Figure 4 demonstrates the relative chlorophyll content of the leaves.

The determination of relative chlorophyll content can be seen on the SPAD values. Due to the different plant densities, and as a result of twin and single rows, a significant difference is formed in vegetation activity).
Post crop results reveal, that the SPAD values forecasted that a higher yield can be expected in the case of twin rows, as a result of greater plant density per unit area.

Figure 3. Fluorescence rates $(\mathbf{F v} / \mathbf{F m})$ in three different times of measurements

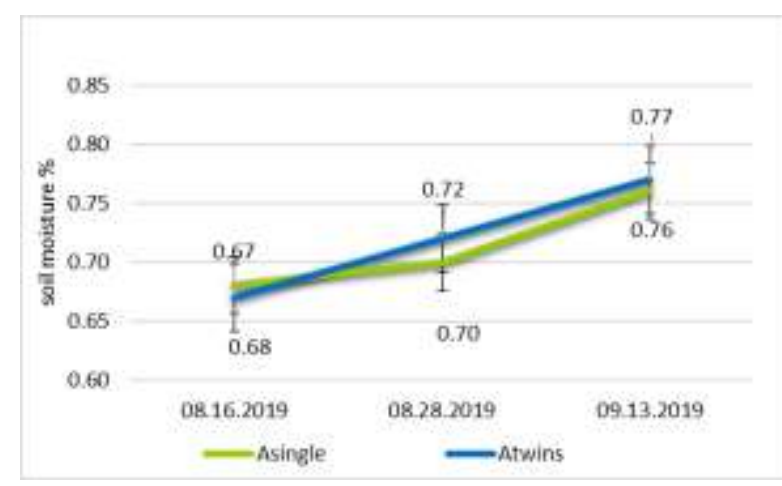

Figure 4. SPAD rates in three different times of measurements, the different letters mark the significant difference between times of measurement

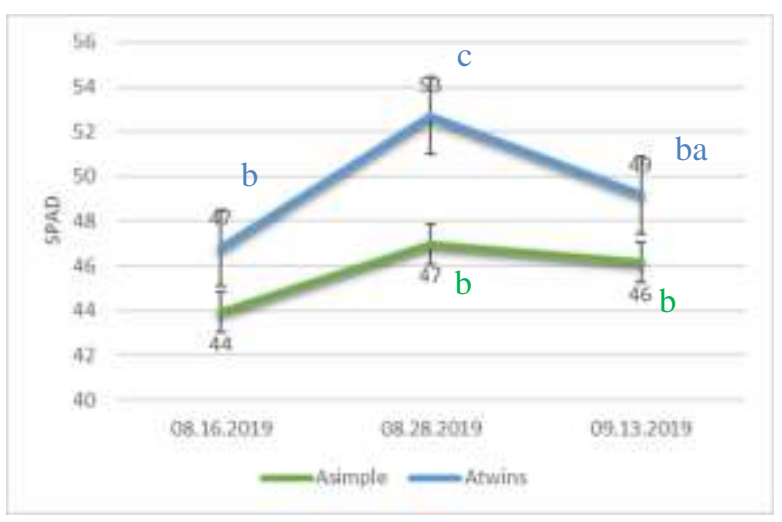

The effect of single and twin rows production on the yield and nutritional value

The comparison of different production methods helps producers choose the most adaptable technologies, which enable efficient production. On the base of the Nedunchezhiyan and Byju (2008) report, $13.1 \mathrm{t} \mathrm{ha}^{-1}$ yield was obtained on sand soil without watering, while Nath et al. (2006) with similar conditions, produced $26 \mathrm{t} \mathrm{ha}^{-1}$ yield with watering. Figure 4 displays the average crop result of the Ásotthalmi 12 cultivar in $\mathrm{t} \mathrm{ha}^{-1}$, where the effect of single and twin row ridge production was compared. The yield of twin rows production was $29.9 \%$ higher than in the case of single row production. Nair (2000) claims, 20-25 tha ${ }^{-1}$ yield can be expected, and the yield depends on the production method, soil, and planting time.

With a $95 \%$ reliability rate, the twin rows method showed a significant higher yield compared to the single row method, where $\mathrm{p}=0.036$ (Figure 5). 
Figure 5. The effect of single and twin rows production on the yield, statistical analyses

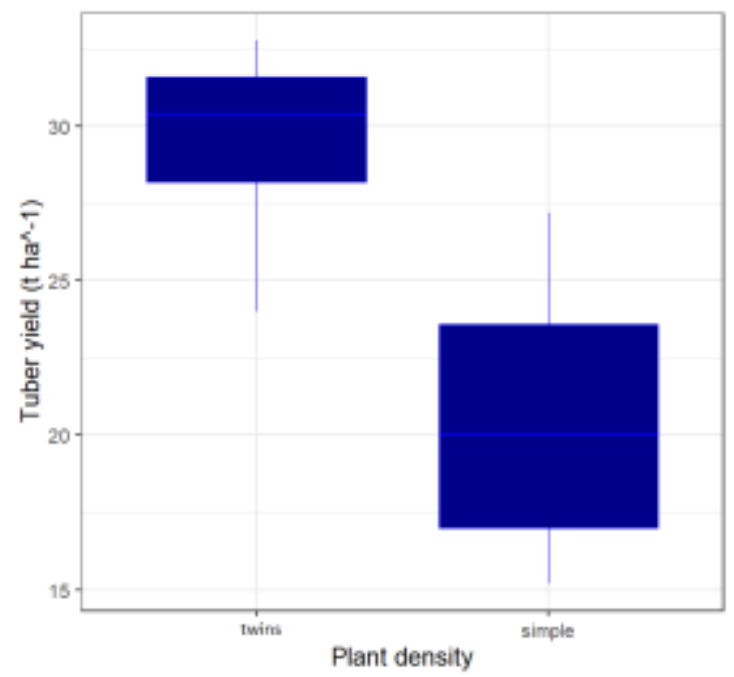

Moreover, the effect of twin and single rows production on nutritional parameters, specifically on Bcarotene, was examined. The Student T test resulted in a $p<0.01$ value. As a result of single row production, the $\beta$-carotene $\left(\mu \mathrm{g} \mathrm{g}^{-1}\right)$ content of the Ásotthalmi 12 cultivar sweet potato was significantly higher. In the case of twin rows production, the average $\beta$-carotin content was $90 \mu \mathrm{g}^{-1}$, while in the case of single row production, the average $\beta$-carotene content was $140 \mu \mathrm{g}^{-1}$ (Figure 6).

Figure 6. The effect of single and twin rows production on the Bcarotene concentration

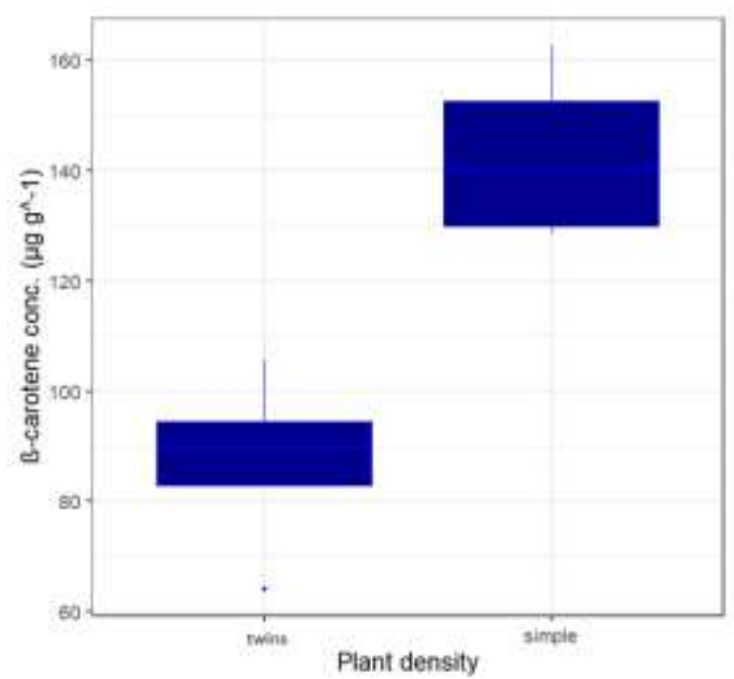

For the determination of the effect of yield on $B$ carotene, linear regression was used, which resulted in $\mathrm{p}<0.001$ and $\mathrm{R}^{2}=0.87$ values (Figure 7). The $\beta$-carotene concentration in the tuber of the Ásotthalmi 12 sweet potato cultivar reduced in proportion to the growth of the yield. For this reason, twin rows production results in greater yield with a significantly lower $\beta$-carotene concentration in the tubers, than in the case of single row production.

Figure 7. The effect of the yield on B-carontene content

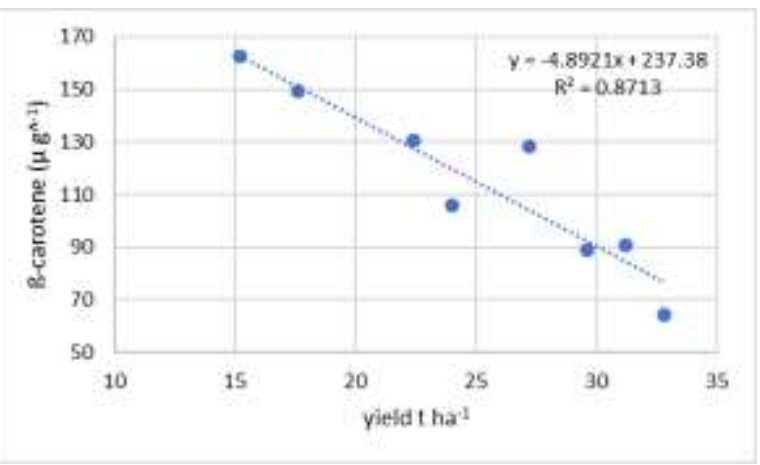

In the case of twin rows production, the greater plant density per unit area leads to the utilization of water surplus. From the same area, more biomass product can be gained with twin rows production, which means that a greater amount of water is used up, and for this reason, the soil dries out faster. Sandy soil is favourable for sweet potato, thus in the case of twin rows production, proper watering is essential in the early stages of production, when there is a high water demand.

The chlorophyll fluorescence results show, that water stress did not affect photosynthetic activity in the last third of vegetation, and there was no significant difference between the various production methods. Sweet potato adopts to both drought and water stress, which can be seen in the rate of photosynthetic activity. For this reason, sweet potato proves to be a highly adaptive, and innovative vegetable, which can adapt to the changing environmental conditions of Hungary. Therefore, sweet potato can be fitted into Hungarian agriculture as a vegetable with high potential. Chlorophyll fluorescence components can be used to measure photosynthesis indirectly. Certain sweet potato cultivars react differently to cooling. Cultivars like TN57, can tolerate cold stress without any problem (Lin et al., 2007). In the future, it might be important to find sweet potato cultivars, that can adapt to Hungarian weather anomalies as well.

The SPAD values show, that there is a significant difference between the twin rows and single row production methods. The higher SPAD values of twin rows production correlate to the greater yield. There is a connection between SPAD index numbers and the expected yield, considering the different SPAD values of the two methods. The studies of Pepó (2020) also claim a strong correlation between SPAD values and the expected yield. 
In the case of different production methods, the twin rows method showed a significantly higher yield, than the single row method. The Ásotthalmi 12 sweet potato cultivar can tolerate higher plant density, the plants do not compete in the case of $90 \mathrm{~cm}$ row spacing, nor in the case of $30 \mathrm{~cm}$ row spacing. The results demonstrate that it is advised to choose the twin rows method since there is nearly a $30 \%$ yield difference between the two methods. In the case of single row production, a significantly higher $\beta$-carotene concentration can be measured, than in the case of twin rows production. The $\beta$-carotene content of the single row cultivated sweet potatoes is $35.71 \%$ greater on average than the $\beta$ carotene content of the twin rows cultivated sweet potatoes. Consequently, with higher plant density we achieved a greater yield, however, the $ß$-carotene concentration in the tubers of sweet potato decreases in line with the increase in yield.

In the case of single row production, $\beta$-carotene content was usually around $140 \mu \mathrm{g}^{-1}$, which is nearly three times higher than the $\beta$-carotin content of the Kwizekumwe cultivar which is only $50 \mu \mathrm{g}^{-1}$ Furthermore, the $\beta$-carotin content of single row production was half of the $B$-carotene content of the SPV-61 cultivar, which is $265 \mu \mathrm{g}^{-1}$ (Ingabrie et al., 2011).

\section{CONCLUSIONS}

As a result, certain plants can no longer be cultivated efficiently because of the changing weather conditions. We can compensate for the loss of such plants, with the production of plants with high potential. One of the endangered plants in Hungary is potato since we can only cultivate a fragment of the amounts that were cultivated decades ago. Hungary has fortunate qualities since we can cultivate every essential food, and we can provide for the whole population. However, we have to adapt to the changing environmental conditions, by introducing new plants to our agriculture, which task demands further research. The changing consumer trends, the growing popularity of health-conscious diet, and the consumption of functional food call for the consideration of new, innovative plants. Sweet potato is a great option, as it can adapt to changing weather conditions, and consumer trends as well. Furthermore, sweet potato has a high nutritional value and can be consumed in many forms, therefore it provides the opportunity of a highquality diet for the population.

Throughout the experiment, we determined the optimal production method of the Ásotthalmi 12 Hungarian sweet potato cultivar, which can adapt to the Hungarian climate. The effect of single and twins rows production on the yield of this cultivar was examined.

Test results showed that twin rows production leads to a nearly $30 \%$ greater yield, than single row production.

The yield growth correlates negatively with the $\beta$ carotene content of the Ásotthalmi 12 sweet potato cultivar.

\section{REFERENCES}

Horváth, L. (1991a): A batáta és termesztése: Az édesburgonya Magyarországon. Kertészet és Szőlészet. 40. 15: 16-17.

Horváth, L. (1991b): A batáta Magyarországon: Védelem, tárolás. Kertészet és Szölészet. 40. 16:

Horváth, L. (1991c): A batáta szaporítása. Kertészet és Szőlészet. 40. 21: 7

http1: https://www.potatopro.com/world/potato-statistics

http2: https://regi.tankonyvtar.hu/hu/tartalom/tamop412A/2011 0085_precizios_novenytermesztes/ch12.html

Ingabire, M.R.-Vasanthakaalam, H. (2011): Comparison of the Nutrient composition of four sweet potato varieties cultivated in Rwanda, American Journal of Nutrition, 1(1), 34-38.

Lin, K.H.-Hwang, W.C.-Lo, H.F. (2007): Chilling stress and chilling tolerance of sweet potato as sensed by chlorophyll fluorescence, Photosynthetica 45 (4): 628-632.

Monostori, T.-Jakab, P.-Váraljai, T.-Váraljai, L.-Marótiné, T.K (2015): A batáta termesztésének lehetőségei Magyarországon, Proceedings of A gazda szemétől a precíziós mezőgazdaságig 120 év a Dél-Alföld agráriumáért, Szegedi Tudományegyetem Mezőgazdasági Kar, 36-42.

Nair, G.M. (2000): Cultural and manurial requirements of sweet potato. In: Mohankumar, C.R.-Nair, G.M.-James, G.-Ravidran, C.S.-Ravi, V. (Eds), Production Technology of Tuber Crops, Central Tuber Crops Researchers Institue Thiruvananthapuram, Kerala, India, pp 44-46.
Nath, R.-Kundu, C.K.-Majumder, A.-Gunri, S.-Chattopadhyay, A.-Sen, H. (2006): Productivity of sweet potato as influenced by cultivar, season and staggered harvesting in laterite ecosystem of West Bengal. In: $14^{\text {th }}$ Triennial Symposium of International Society of Tropical Root Crops, 20-26 November 2006, Central Tuber Crops Research Institute, Thiruvananthapuram, India, pp 23.

Nedunchezhiyan, M.-Byju, G. (2008): Performance of sweet potato (Iponomea batatas) varieties under shaded and open field conditions., Indian Journal of Agriculture Sciences 78 (11), 974977.

Nedunchezhiyan, M.-Byju, G.-Jata, K.S. (2012): Sweet Potato Agronomy, Fruit, Vegetable and Cereal Science and Biotechnology 6, Global Science Book.

Patil, Y.B.-Patil, A.A.-Madalagei, B.B.-Patil, V.S. (1992): Effect of levels of $\mathrm{N}$ and $\mathrm{K}$ and inter row spacing on growth and yield of sweet potato. Journal of Root Crops 18(1), 58-61.

Pepó, P. (2020): Correlation analysis of the SPAD readings and yield of sweet potato (Ipomoea batatas L.) under different agrotechnical conditions, AJCS 14(05):761-765.

Yasuhiro, T.-Takahiro, N.-Tadahiro, N. (1993): HPLC Determination of $\beta$-carotene contennt of sweet potato cultivars and its relationship with colour values, Japan. J. Breed. 43:421427. 
